\title{
Sistem Pakar Deteksi Buta Warna Menggunakan Metode Neural Network
}

\author{
Expert System of Blind Detection Color Using Neural Network Method
}

\author{
Lugas Luqmanul Hakim¹, Supatman²
}

\begin{abstract}
1,2 Program Studi Teknik Informatika, Fakultas Teknologi Informasi, Universitas Mercu Buana Yogyakarta, Jl.
Wates Km. 10 Yogyakarta 55753, Indonesia

Email: widatinmayasari@gmail.com¹, supatman@mercubuana-yogya.ac.id²
\end{abstract}

\begin{abstract}
ABSTRAK
Mata merupakan salah satu organ tubuh manusia yang memiliki fungsi sebagai alat penglihatan, dengan pengelihatannya manusia dapat menikmati keindahan ciptaan Yang Maha Kuasa. Buta warna merupakan salah satu kelainan mata yang disebabkan ketidakmampuan sel-sel kerucut mata untuk menangkap suatu spektrum warna tertentu yang disebabkan oleh faktor genesis. Tentu kelainan ini memberikan dampak tersendiri pada penderitanya. Metode ishihara adalah salah satu metode yang paling populer digunakan dalam melakukan tes buta warna, yaitu berupa lembar-lembar yang bergambar titik-titik yang membentuk pola tertentu yang akan terbaca oleh mata normal.

Penelitian ini mendesain sistem pakar untuk mendeteksi buta warna pada manusia. Metode neural network yang dilearning dengan lembar-lembar ishihar dipergunakan sebagai basis data cerdas sistem pakar untuk dapat mendeteksi jenis buta warna seseorang melalui tes-tes lembar ishihara yang di berikan. Kemampuan sistem pakar ini dideain untuk mengenali empat jenis mata yaitu mata normal, buta warna parsial, buta warna parsial defisiensi warna merah hijau dan buta warna total.

Data pelatihan yang digunakan untuk melatih sistem ini berjumlah 35 data dan pengujian 33 data yang terbagi menjadi empat kelas. Hasil pelatihan dan pengujian pada parameter neural network berjenis LVQ alfa 0,5 dengan perincian pengujian buta warna parsial sebanyak tiga, buta warna parsial defisiensi warna merah hijau sebanyak enam dan buta warna total sebanyak dua diperoleh unjukkerja dengan tingkat persentase keberhasilan yaitu $100 \%$.
\end{abstract}

Kata kunci: Buta Warna, Sistem Pakar, Neural Network, Lembar Ishihara

\begin{abstract}
The eye is one of the organs of the human body that has a function as a tool of vision, with the sight of humans can enjoy the beauty of the creation of the Almighty. Color blindness is one of the eye disorders caused by the inability of the eye's cone cells to capture a particular color spectrum caused by the genesis factor. Of course this disorder gives its own impact on the sufferer. The ishihara method is one of the most popular methods used in performing color blind tests, which are pieces of dotted images that form certain patterns that will be read by normal eyes.

This study designs expert systems to detect color blindness in humans. The neural network method that is studied with ishihar sheets is used as intelligent expert system database to be able to detect the type of color blind person through ishihara test sheets given. The ability of this expert system is designed to recognize four types of eyes: normal eyes, partial color blindness, partial red color blindness deficiency and total color blindness.

Training data used to train this system amounted to 35 data and testing 33 data divided into four classes. The result of training and testing on LVQ alpha network parameter 0,5 with partial blindness testing as much as three, partial red color deficiency blindness of six red color and total color blindness of two obtained performance with $100 \%$ success rate.
\end{abstract}

Keywords: Color Blindness, Expert System, Neural Network, Ishihara Sheet 


\section{PENDAHULUAN}

Kebutaan bisa dikategorikan menjadi beberapa macam. Kebutaan karena buta warna atau kebutaan total (dalam artian tidak bisa melihat apa-apa). Buta warna merupakan kelainan genetik yang penyebabnya bisa dari keturunan ataupun kesalahan dalam mengkonsiumsi obat. Buta warna menjadi masalah tersendiri bagi masyarakat, masalahnya banyak instansi-instansi yang tidak memperbolehkan anggotanya mengidap buta warna. Untuk mengetahui seseorang mengidap buta warna atau tidak, sekarang yang bisa di lakukan adalah melalui tes di dokter, pada saat ini peralatan yang di gunakan dokter adalah buku yang di sebut dengan buku ishihara test yang terdiri dari lembaran-lembaran yang terdapat titik-titik dengan berbagai warna dan ukuran. Titik-titik itu di atur sedemikian rupa, sehingga pengidap buta warna tidak akan bisa membacanya.

Dengan uji buta warna menggunakan metode Ishihara, dokter dapat menyimpulkan pasien mengidap buta warna atau tidak, serta mengetahui jenis buta warna dan penyebab kebutaan dari pasien. Buku test Ishihara berisi cetakan gambar pseudo-isochromatic akan mengalami perubahan warna karena bertambahnya usia buku, warna yang ada pada pseudo-isochromatic akan pudar atau kusam jika terlalu lama disimpan, atau terkena cahaya, kekusaman warna akan merubah keaslian plat untuk alat uji sehingga akan mempengaruhi keakuratan hasil test Selain pemeliharaan buku test yang sulit, harga dari buku test tersebut sangat mahal.

Peran teknologi sangatlah penting untuk kehidupan manusia. Masalah tes buta warna seperti pemaparan ini pun dapat di atasi menggunakan teknologi. Pemanfaatan sistem pakar dapat digunakan untuk membantu mendeteksi buta warna. Sistem ini juga kemudian hari dapat digunakan untuk menggantikan sistem tes buta warna dengan buku atau cara tradisional.

\section{TINJAUAN PUSTAKA}

Penelitian dilakukan oleh Ananto (2011), dengan judul Implementasi Sistem Bantuan Penderita Buta Warna: Desain Antarmuka Pengguna, Sistem Tes Buta Warna Dengan Ishihara, dan Transformasi Warna Pada Sistem Realitas Tertambah. Penelitian tentang pembuatan perangkat lunak yang bukan hanya sebagai tes buta warna tetapi juga membantu pengidap buta warna untuk mengetahui warna sebuah objek yang tidak terlihat. Pembuatan perangkat lunak ini menggunakan pemrograman mobile. Meteode pengujian buta warna menggunakan metode ishihara dan dilengkapi juga dengan sistem augmented reality sehingga pemanfaatan perangkat lunak bisa langsung dari kamera smartphone. Penerapan metode ishihara sebagai tools pengujian buta warna memberikan hasil akurasi yang tinggi dengan persentase $100 \%$.

Penelitian dilakukan oleh Widianingsih, dkk (2010), dengan judul Aplikasi Tes Buta Warna Dengan Metode Ishihara Berbasis Komputer. Penelitian ini tentang pembuatan perangkat lunak untuk tes buta warna. Pembuatan perangkat lunak menggunakan pemrograman desktop. Perangkat lunak ini menggunakan 24 lembar ishihara, dan pembuatannya hanya menggunakan logika if else. Hasil dari penelitian ini adalah sebuah aplikasi tes buta warna yang digunakan di POLTABES Samarinda.

Penelitian dilakukan oleh Purnamasari (2015), dengan judul Tes Buta Warna Metode Ishihara Berbasis Komputer (Kelas XI Jurusan Teknik Instalasi Tenaga Listik SMK Negeri 3 Semarang). Tentang pembuatan perangkat lunak tes buta warna. Pembuatan perangkat lunak menggunakan metode ishihara dan menggunakan 17 lembar ishihara, Penelitian ini menggunakan metode research and development dengan teknik pengumpulan data berupa angket kepada responden. Hasil output dari perangkat lunak ini hanya menampilkan apakah pengguna mengidap buta warna parsial atau total, tidak ada penjabaran lagi bila pengguna mengidap buta warna parsial.

Penelitian dilakukan oleh Murti, dkk (2011), dengan judul Metode Pendiagnosa Kebutuhan Warna Dengan Menggunakan Metode Ishihara. Penelitian ini tentang pembuatan perangkat lunak sistem pakar yang digunakan sebagai alat bantu tes pemeriksaan gangguan pengelihatan terhadap warna. Penelitian ini menggunakan metode mekanisme inferensi untuk pengujian aturan dengan teknik penalaran maju (forward reasoning). Metode ishihara yang digunakan menggunakan 38 lembar. Hasil dari penelitian ini adalah rancangan model dapat digunakan sebagai alat bantu untuk tes pemeriksaan gangguan penglihatan terhadap warna, dengan hasil yang sama dengan pengujian manual.

Penelitan dilakukan oleh Prabawati (2015), dengan judul Sistem Pakar Diagnosa Buta Warna Berbasis Android. Penelitian ini berfokus pada pembuatan aplikasi deteksi buta 
warna berbasis android. Metode Forward chaining digunakan dalam pembuatan aplikasi ini. Hasil penelitian menunjukkan bahwa sistem pakar diagnosa buta warna mampu mendiagnosa buta warna secara valid kepada masyarakat umum dengan sensitivitas yang dibangun berada pada kategori valid dengan nilai $100 \%$, tingkat spesifisitas pada kategori valid sebesar $80 \%$, nilai akurasi dari keseluruhan aplikasi sebesar 90\%. Kesimpulan dari penelitian ini adalah aplikasi yang dibuat merupakan aplikasi dengan tingkat sensitivitas dan spesifisitas kesehatan dapat diterapkan sebagai pengganti tes buta warna secara manual.

Penelitian ini berfokusi pada pembuatan perangkat lunak yang digunakan untuk tes buta warna. Hasil yang di inginkan menunjukkan buta warna parsial atau buta warna total. Metode neural network digunakan sebagai mesin inferensi pada sistem ini. Metode neural network ini memiliki kelebihan yaitu sistem cerdas, artinya sistem dapat memberikan jawaban apabila input yang diberikan tidak sama persis dengan aturan pakar. Dan juga perangkat lunak berbasis web ini berjalan di perangkat yang lebih mudah di gunakan sehingga masyarakat dapat menggunakan perangkat lunak ini untuk melakukan deteksi buta warna.

Penelitian dilakukan oleh Murti, dkk (2011), dengan judul Metode Pendiagnosa Kebutuhan Warna Dengan Menggunakan Metode Ishihara. Penelitian ini tentang pembuatan perangkat lunak sistem pakar yang digunakan sebagai alat bantu tes pemeriksaan gangguan pengelihatan terhadap warna. Penelitian ini menggunakan metode mekanisme inferensi untuk pengujian aturan dengan teknik penalaran maju (forward reasoning). Metode ishihara yang digunakan menggunakan 38 lembar. Hasil dari penelitian ini adalah rancangan model dapat digunakan sebagai alat bantu untuk tes pemeriksaan gangguan penglihatan terhadap warna, dengan hasil yang sama dengan pengujian manual.

Penelitan dilakukan oleh Prabawati (2015), dengan judul Sistem Pakar Diagnosa Buta Warna Berbasis Android. Penelitian ini berfokus pada pembuatan aplikasi deteksi buta warna berbasis android. Metode Forward chaining digunakan dalam pembuatan aplikasi ini. Hasil penelitian menunjukkan bahwa sistem pakar diagnosa buta warna mampu mendiagnosa buta warna secara valid kepada masyarakat umum dengan sensitivitas yang dibangun berada pada kategori valid dengan nilai $100 \%$, tingkat spesifisitas pada kategori valid sebesar $80 \%$, nilai akurasi dari keseluruhan aplikasi sebesar 90\%. Kesimpulan dari penelitian ini adalah aplikasi yang dibuat merupakan aplikasi dengan tingkat sensitivitas dan spesifisitas kesehatan dapat diterapkan sebagai pengganti tes buta warna secara manual.

Penelitian ini berfokusi pada pembuatan perangkat lunak yang digunakan untuk tes buta warna. Hasil yang di inginkan menunjukkan buta warna parsial atau buta warna total. Metode neural network digunakan sebagai mesin inferensi pada sistem ini. Metode neural network ini memiliki kelebihan yaitu sistem cerdas, artinya sistem dapat memberikan jawaban apabila input yang diberikan tidak sama persis dengan aturan pakar. Dan juga perangkat lunak berbasis web ini berjalan di perangkat yang lebih mudah di gunakan sehingga masyarakat dapat menggunakan perangkat lunak ini untuk melakukan deteksi buta warna.

\subsection{Metode Ishihara}

Tes ishihara adalah salah satu cara untuk mengetahui buta warna pada seseorang. Tes ini dikembangkan oleh Dr. Shinobu Ishihara dan pertama kali dipublikasikan pada tahun 1917 di Jepang. Tes ishihara terdiri dari beberapa lembaran atau plat yang didalamnya terdapat titik-titik dengan berbagai warna dan ukuran. Titik-titik berwarna tersebut disusun sehingga membentuk lingkaran. Warna titik itu di buat sedemikian rupa sehingga orang buta warna tidak akan mampu melihat objek atauh huruf yang ada di dalam gambar tersebut

Terdapat 17 macam plat atau lembar dalam tes ishihara, dari setiap lembar yang di gunakan dapat diketahui jenis buta warna. 17 lembar tersebut yaitu:

a. Plat no. 1

Orang normal dan mereka yang buta warna parsial akan terlihat 12, sedangkan seorang buta warna total tidak akan melihat apapun. Plat nomor satu seperti Gambar 1.

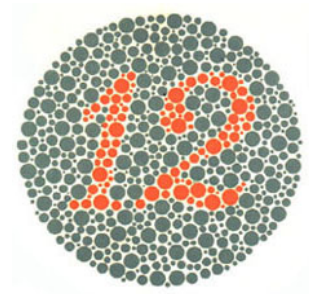

Gambar 1. Plat Nomor 1 (Rokhim, 2015) 
b. Plat no. 2 dan 3

Pada plat kedua, mata normal akan terbaca delapan. Mereka yang menderita gangguan penglihatan merah-hijau akan membaca tiga. Plat kedua seperti Gambar 2.

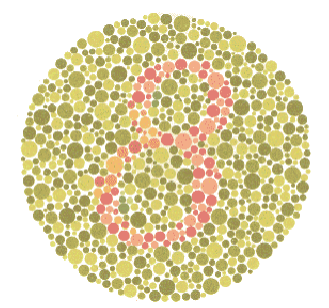

Gambar 2. Plat Nomor 2 (Rokhim, 2015)

Pada plat ke tiga, mata normal akan terbaca 29. Tetapi penderita gangguan merah-hijau akan terbaca 70. Plat ketiga seperti Gambar 3.

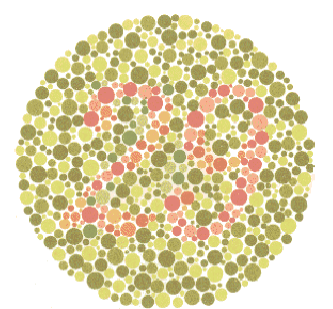

Gambar 3. Plat Nomor 3 (Rokhim, 2015)

c. Plat no. 4 sampai 7

Pada plat ke empat, mata normal akan terbaca lima. Tetapi penderita gangguan penglihatan merah-hijau akan terbaca dua. Plat ke empat seperti Gambar 4.

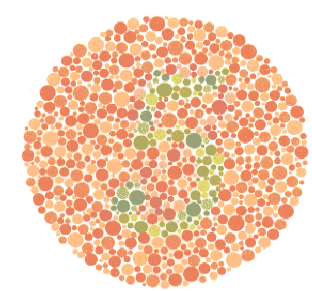

Gambar 2. Plat Nomor 4 (Rokhim, 2015)

Pada plat ke lima, mata normal akan terbaca tiga. Tetapi penderita gangguan penglihatan merah-hijau akan terbaca lima. Plat ke lima seperti Gambar 5.

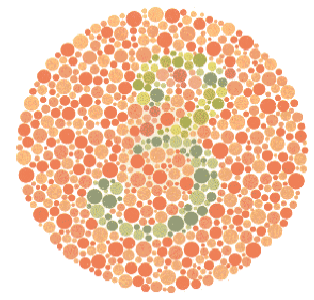

Gambar 3. Plat Nomor 5 (Rokhim, 2015)
Pada plat ke enam, mata normal akan terbaca 15. Tetapi penderita gangguan penglihatan merah-hijau akan terbaca 17 . Plat ke lima seperti Gambar 6.

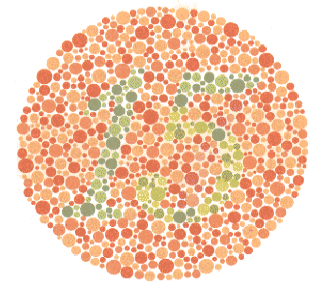

Gambar 4. Plat Nomor 6 (Rokhim, 2015)

Pada plat ke tujuh, mata normal akan terbaca 74. Tetapi penderita gangguan penglihatan merah-hijau akan terbaca 21 . Plat ke tujuh seperti Gambar 7.

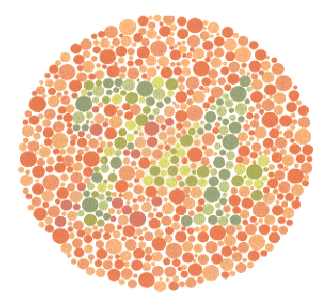

Gambar 5. Plat Nomor 7 (Rokhim, 2015)

d. Plat no. 8 dan 9

Pada plat delapan, mata normal akan terbaca enam dan pada plat Sembilan akan terbaca 45. Tetapi penderita buta warna tidak dapat membaca satu nomor pun yang ada di plat tersebut. Plat delapan dan Sembilan seperti Gambar 8 dan Gambar 9.

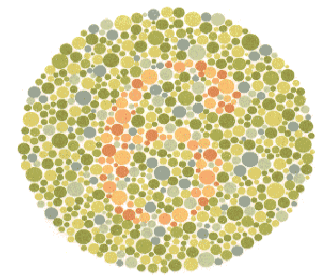

Gambar 6. Plat Nomor 8 (Rokhim, 2015)

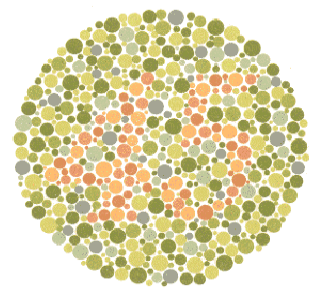

Gambar 7. Plat Nomor 9 (Rokhim, 2015)

e. Plat no. 10 sampai 13

Pada plat 10, mata normal akan terbaca lima, plat 11 akan terbaca tujuh, plat 12 akan terbaca 16 dan plat 13 akan terbaca 73. Tetapi penderita buta warna tidak akan 
terbaca angka apapun pada plat-plat tersebut. Plat 10 sampai 13 dapat di lihat pada Gambar 10 sampai Gambar 13.

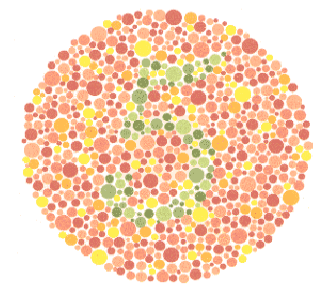

Gambar 8. Plat Nomor 10 (Rokhim, 2015)

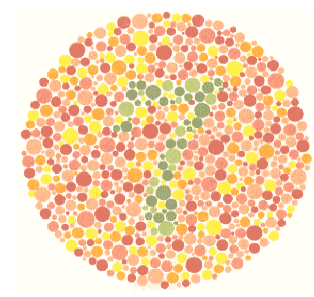

Gambar 9. Plat Nomor Sebelas (Rokhim, 2015)

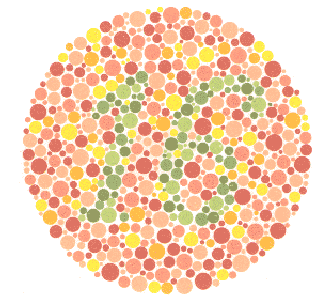

Gambar 10. Plat Nomor 12 (Rokhim, 2015)

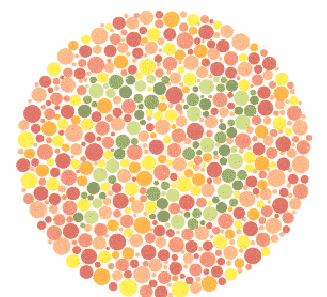

Gambar 11. Plat Nomor 13 (Rokhim, 2015)

\section{f. Plat no. 14 dan 15}

Sebagian besar orang yang menderita gangguan penglihatan merah-hijau akan membaca lima pada plat 14 dan membaca 15 pada plat 5. Sebagian orang normal tidak akan membaca angka apapun. Plat 14 dan 15 dapat dilihat pada Gambar 14 dan Gambar 15.

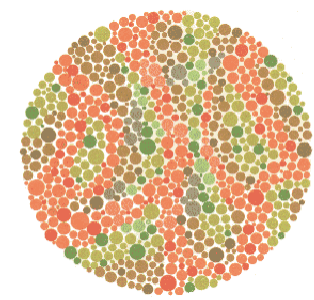

Gambar 12 Plat Nomor 14 (Rokhim, 2015)

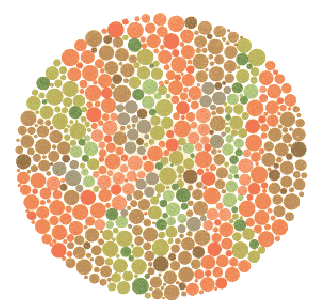

Gambar 13. Plat Nomor 15 (Rokhim, 2015)

g. Plat no. 16 dan 17

Pada plat 16 mata normal akan terbaca 26 dan pada plat 17 akan terbaca 42 . Pada penderita protonopia dan protonomalia yang parah pada plat 16 akan terbaca enam dan pada plat 17 akan terbaca dua. Plat 16 dan 17 dapat dilihat pada Gambar 16 dan Gambar 17.

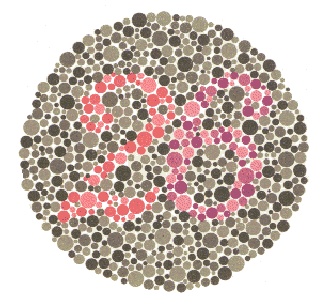

Gambar 14. Plat Nomor 16 (Rokhim, 2015)

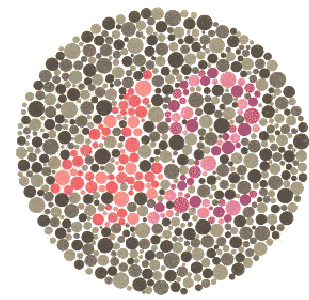

Gambar 15. Plat Nomor 17 (Rokhim, 2015)

\subsection{Buta Warna dan Karakteristiknya}

Sebagai salah satu faktor yang berkaitan dengan penglihatan, buta warna kini menjadi salah satu tolak ukur untuk sebuah persyaratan masuk universitas atau dunia kerja. Pembedaan persepsi terhadap suatu warna sangat dibutuhkan dalam bidang-bidang tertentu, seperti teknik dan kedokteran. Warna berperan penting dalam kehidupan sehari-hari, warna sering dijadikan sebagai tanda atau sekedar estetika.

Kondisi buta warna mulai diketahui sejak tahun 1879 yang dipublikasikan oleh John Dalton dalam tulisan esainya. Hal tersebut menjadi awal dikenalnya buta warna dalam literatur, sekaligus mendorong untuk memberikan bukti konklusif atas persepsi warna pada penyandang buta warna.

Perbedaan mendasar antara penderita buta warna dan kebanyakan orang adalah 
bahwa beberapa warna yang muncul berbeda jika dilihat mata normal, namum terlihat sama pada penyandang buta warna. Penderita buta warna memiliki kelemahan terhadap penglihatan, dengan kurangnya kemampuan untuk membedakan warna, saturasi dan kecerahan.

Pada dasarnya, penglihatan terhadap warna ditentukan oleh pembedaan tiga kualitas faktor warna, yaitu hue (jenis warna, seperti merah atau hijau dan sebagainya), saturation (warna tunggal atau warna campuran), brightness (intensitas warna terang atau gelap). Ketiga faktor untuk penglihatan warna tersebut dipengaruhi oleh fungsi sel konus atau sel kerucut. Sel fotosensitif pada mata yang disebut sel kerucut tersebut memungkinkan mata melihat warna. Sel kerucut terletak di tengahtengah retina dan mengandung tiga jenis pigmen fotosensitif yang dapat mendeteksi warna merah, hijau, dan biru. Seorang buta warna memiliki kelemahan atau bahkan sama sekali tidak memiliki pigmen tersebut.

Sel kerucut menyerap foton dan mengirim sinyal listik ke otak. Tiga jenis sel kerucut memiliki sensitifitas spekral yang berbeda. L-Cones untuk menyerap (absorpsi) panjang gelombang yang tinggi. M-Cones untuk menyerap panjang gelombang menengah. Dan S-Cones untuk menyerap panjang gelombang yang rendah secara efektif. Berdasarkan fungsi sel tersebut, akibatnya cahaya dipersepsikan terdiri dari tiga jenis (L, m, s), 1 (long), m (middle), dan s (short).

Merepresentasikan jumlah foton yang diserap oleh masing-masing L-, M-, dan SCones. Oleh karna itu penglihatan normal disebut juga trikromasi normal.

Kelainan pada sel kerucut tersebut, menyebabkan kemungkinan terjadinya buta warna. Terdapat tiga jenis gangguan penglihatan terhadap warna.

\section{Monokromasi}

Monokromasi adalah keadaan ketika seseorang hanya memiliki sebuah sel kerucut (cones) atau tidak berfungsinya semua sel kerucut. Buta warna jenis ini biasa disebut buta warna total. Buta warna total sangat jarang terjadi dan dialami oleh sekitar 1 dari 10.000 penduduk di dunia. Monokromasi ada dua jenis, yaitu rod monochromacy dan cone monochromacy (Rokhim, 2015).

a. Rod monochromacy adalah jenis buta watna yang sangat jarang terjadi, yaitu ketidakmampuan membedakan warna sebagai akibat dari tidak berfungsinya semua cones retina. Penderita rod monochromacy tidak dapat membedakan warna sehingga yang terlihat hanya hitam, putih dan abu-abu saja.

b. Cone monochromacy adalah tipe monokromasi yang disebabkan oleh tidak berfungsinya dua sel kerucut. Penderita buta warna jenis ini masih dapat melihat satu warna tertentu, karena masih memiliki sel kerucut yang berfungsi.

\section{Dikromasi}

Dikromasi adalah jenis buta warna ketika salah satu dari tiga sel kerucut tidak ada atau tidak berfungsi. Dikromasi dibagi menjadi tiga bagian berdasarkan sel pigmen yang rusak (Rokhim, 2015).

a. Protanopia adalah salah satu jenis dikromasi yang disebabkan oleh tidak adanya fotoreseptor retina merah. Pada penderita protanopia, penglihatan terhadap warna merah tidak ada. Dikromasi jenis ini terjadi pada $1 \%$ dari seluruh pria. Protanopia juga dikenal sebagai buta warna merah hijau.

b. Dentanopia adalah gangguan penglihatan terhadap warna yang disebabkan tidak adanya fotoreseptor retina hijau. Hal ini menimbulkan kesulitan dalam membedakan hue pada warna merah dan hijau.

c. Trianopia adalah keadaan ketika seseorang tidak memiliki sel kerucut gelombang pendek. Seorang yang menderita tritanopia akan kesulitan membedakan warna biru-kuning dan merupakan jenis dikromasi yang sangat jarang dijumpai.

\section{Kelainan Trikromasi (Animalous} Tricharmacy)

Penyimpangan yang dialami dengan penglihatan trikromasi ini disebabkan oleh faktor keturunan atau kerusakan mata setelah dewasa. Penderita anomalous trikromasi memiliki tiga sel kerucut tetapi terjadi kerusakan mekanisme sensitivitas terhadap salah satu dari tiga sel reseptor warna tersebut (Rokhim, 2015).

a. Protanomali adalah kelainan longwavelength pigment (merah), sehingga menyebabkan rendahnya sensitifitas terhadap cahaya merah. Artinya pendetita protanomali tidak akan mampu membedakan warna dan melihat campuran warna yang dapat di lihat oleh 
mata normal. Penderita juga akan mengalami penglihatan yang buram terhadap spectrum merah. Hal ini mengakibatkan mereka dapat salah membedakan warna merah dan hijau.

b. Deoteranomali disebabkan oleh kelainan pada bentuk pigmen middle-wavelength (hijau). Sama halnya dengan protanomali, deuteronomali tidak mampu melihat perbedaan kecil pada nilai hue dalam area spectrum warna merah, jingga, kuning dan hijau. Penderita salah menafsirkan hue dalam region warna tersebut, karena hue-nya lebih mendekati warna merah. Penderita deutronnmali tidak memiliki masalah dalam hilangnya penglihatan terhadap tingkat kecerahan.

c. Trianomali adalah jenis anomalus trichromacy yang sangat jarang terjadi, baik pada pria maupun wanita. Pada trianomali kelainan terdapat pada shortwavelength pigment (biru). Pigmen biru ini bergeser ke area hijau dari spectrum warna.

\subsection{Konsep Dasar Sistem Pakar}

Konsep dasar dari sistem pakar yaitu meliputi keahlian (expertise), ahli (experts), pemindahan keahlian (transfering expertise), inferensi (inferencing), aturan (rules) dan kemampuan memberikan penjelasan (explanation capability).

Keahlian (expertise) adalah pengetahuan yang mendalam tentang suatu masalah tertentu, dimana keahlian bisa diperoleh dari pelatihan/pendidikan, membaca dan pengalaman dunia nyata (Arhami, 2005). Ada dua macam pengetahuan yang tidak ahli. Pengetahuan dari sumber ahli yang dapat digunakan untuk mengambil keputusan dengan cepat dan tepat.

Ahli (experts) adalah seorang yang memiliki keahlian tentang suatu hal dalam tingkatan tertentu, ahli dapat menggunkan suatu permasalahan yang ditetapkan dengan beberapa cara yang berubah-ubah dan merubahnya kedalam bentuk yang dapat dipergunakan oleh dirinya sendiri dengan cepat dan cara pemecahan yang mengesankan (Arhami, 2005).

Ahli seharusnya dapat untuk menjelaskan hasil yang diperoleh, mempelajari sesuatu yang baru tetang domain masalah, merestrukturisasi pengetahuan kapan saja yang diperlukan dan menentukan apakah keahlian mereka relevan atau saling berhubungan.

\subsection{Neural Network}

Jaringan syaraf tiruan atau jaringan neural adalah sistem pemrosesan informasi yang mempunyai karakteristik kinerja tertentu seperti jaringan neurol biologis. Jaringan syaraf tiruan (dalam pembahasan berikutnya disebut jaringan neural jasa) telah dikembangkan sebagai generalisasi model matematik dari kognisi manusia atau biologi neural (Widodo, 2005).

\section{METODOLOGI}

\subsection{Akuisisi Pengetahuan Buta Warna}

Akuisisi pengetahuan merupakan kegiatan mencari dan mengumpulkan data yang akan diterapkan pada sistem, tahap ini juga merupakan tahapan awal yang dilakukan dalam pembuatan sistem. Pengetahuan dapat diakuisisi dari seorang pakar melalui buku yang dibuatnya. Dari buku tersebut peneliti mengakuisisi pengetahuan yang telah di tulis pakar dalam buku.

\subsection{Perancangan Basis Pengetahuan}

Basis pengetahuan mengandung pengetahuan untuk pemahaman dalam penyelesaian masalah yang digunakan dalam sistem kecerdasan buatan. Basis pengetahuan digunakan untuk penarikan kesimpulan yang merupakan hasil dari proses pelacakan.

\subsection{Perancangan Database}

Perancangan database merupakan proses untuk menentukan isi data yang dibutuhkan untuk mendukung rancangan sistem. Model rancangan database yang dibangun adalah model relationship dimana seluruh tabel saling berhubungan satu dengan yang lainnya.

\subsection{Inferensi Pengetahuan dengan Learning Vector Quantization}

Learning Vector Quantization adalah sebuah metode klasifikasi dimana setiap unit output mempresentasikan sebuah kelas. Learning Vector Quantization digunakan untuk pengelompokan, dimana jumlah kelompok sudah ditentukan arsitekturnya (target/kelas sudah ditentukan). Sehingga dapat melakukan proses identifikasi untuk mengetahui jenis-jenis buta warna. Salah satu kelebihan dari LVQ adalah model yang di hasilkan dapat diperbaharui secara bertahap yang menjadikan alasan pemakaian LVQ pada sistem pakar deteksi buta warna. 


\section{ANALISIS DAN PEMBAHASAN}

Hasil pengujian yang dilakukan pada sistem pakar deteksi buta warna menunjukkan unjuk kerja sistem sesuai dengan keterangan yang didapatkan dari pakar. Dalam penelitian ini menggunakan 35 data pelatihan dan menggunakan 33 data uji. Sementara untuk kelas dalam penelitian terdapat empat kelas yaitu adalah Buta Warna Parsial Defisiensi Warna Merah Hijau, dan kelas empat adalah Mata Normal. Learning Vector Quantization (LVQ) digunakan sebagai mesin inferensi untuk mendeteksi buta warna. Dari hasil pengujian maka dihasilkan tingkat persentase keberhasilan yaitu $100 \%$.

Proses pelatihan pada jaringan $L V Q$ digunakan parameter yang digunakan untuk mengetahui persentase keberhasilan tertinggi. Pelatihan dilakukan untuk mencari bobot akhir yang digunakan dalam proses pengujian. Parameter LVQ dalam pelatihan ditunjukkan pada Tabel 1 .

Tabel 1. Parameter Learning Vector Quantization

\begin{tabular}{|l|l|}
\hline Parameter & Nilai \\
\hline Jumlah data pelatihan & 35 \\
\hline Jumlah data uji & 33 \\
\hline Jumlah pola target & 4 \\
\hline Variasi laju pelatihan $(\alpha)$ & $0.1 ; 0.3 ; 0.5$ \\
\hline Update laju pelatihan & $\begin{array}{l}\alpha=\alpha-\alpha(\mathrm{dec} \\
\alpha)\end{array}$ \\
\hline $\begin{array}{l}\text { Variasi penurunan laju } \\
\text { pelatihan (dec } \alpha)\end{array}$ & $0.1 ; 0.25 ; 0.5 ;$ \\
\hline Maksimal iterasi & 0.75 \\
\hline
\end{tabular}

Setelah didapatkan data pelatihan dan bobot awal. Tahap selanjutnya adalah melakukan pelatihan terhadap data pelatihan. Dalam menentukan hasil kerja identifikasinya bisa dilakukan dengan mengubah parameter laju pelatihan awal (alfa) dan penurunan laju pelatihan (dec alfa). Untuk target ada empat pola, dengan maksimum iterasi sebesar 250 . Hasil kinerja pelatihan dengan LVQ dapat dilihat pada Tabel 2.

Tabel 2. Hasil kinerja pelatihan dengan LVQ

\begin{tabular}{|l|l|l|l|}
\hline (dec alfa) & (alfa) & Iterasi & $\begin{array}{c}\text { Unjuk kerja } \\
(\%)\end{array}$ \\
\hline \multirow{3}{*}{0.1} & 0.5 & 5 & $82.86 \%$ \\
\cline { 2 - 4 } & 0.3 & 6 & $77.14 \%$ \\
\cline { 2 - 4 } & 0.1 & 6 & $45.71 \%$ \\
\hline \multirow{3}{*}{0.25} & 0.5 & 5 & $82.86 \%$ \\
\cline { 2 - 4 } & 0.3 & 5 & $74.29 \%$ \\
\cline { 2 - 4 } & 0.1 & 7 & $48.57 \%$ \\
\hline \multirow{3}{*}{0.5} & 0.5 & 4 & $71.43 \%$ \\
\cline { 2 - 4 } & 0.3 & 5 & $80 \%$ \\
\cline { 2 - 4 } & 0.1 & 5 & $51.43 \%$ \\
\hline
\end{tabular}

\begin{tabular}{|l|l|l|l|}
\hline (dec alfa) & (alfa) & Iterasi & $\begin{array}{c}\text { Unjuk kerja } \\
\mathbf{( \% )}\end{array}$ \\
\hline \multirow{3}{*}{0.75} & 0.5 & 5 & $100 \%$ \\
\cline { 2 - 4 } & 0.3 & 6 & $85.71 \%$ \\
\cline { 2 - 4 } & 0.1 & 8 & $54.29 \%$ \\
\hline
\end{tabular}

Hasil pengenalan data uji menggunakan bobot akhir yang diperoleh dari alfa 0.5 dan dec alfa 0.75 dapat dilihat pada Tabel 3 .

Tabel 3. Hasil pengenalan data uji menggunakan bobot akhir yang diperoleh dari alfa 0.5 dan $\mathrm{dec}$ alfa 0.75

\begin{tabular}{|c|c|c|c|}
\hline $\begin{array}{c}\text { Data Uji } \\
\text { ke- }\end{array}$ & Target & Hasil (T) & Keterangan \\
\hline 1 & 4 & 4 & Benar \\
\hline 2 & 4 & 4 & Benar \\
\hline 3 & 4 & 4 & Benar \\
\hline 4 & 4 & 4 & Benar \\
\hline 5 & 4 & 4 & Benar \\
\hline 6 & 4 & 4 & Benar \\
\hline 7 & 4 & 4 & Benar \\
\hline 8 & 4 & 4 & Benar \\
\hline 9 & 4 & 4 & Benar \\
\hline 10 & 4 & 4 & Benar \\
\hline 11 & 4 & 4 & Benar \\
\hline 12 & 4 & 4 & Benar \\
\hline 13 & 4 & 4 & Benar \\
\hline 14 & 4 & 4 & Benar \\
\hline 15 & 4 & 4 & Benar \\
\hline 16 & 4 & 4 & Benar \\
\hline 17 & 4 & 4 & Benar \\
\hline 18 & 4 & 4 & Benar \\
\hline 19 & 4 & 4 & Benar \\
\hline 20 & 4 & 4 & Benar \\
\hline 21 & 4 & 4 & Benar \\
\hline 22 & 4 & 4 & Benar \\
\hline 23 & 1 & 1 & Benar \\
\hline 24 & 1 & 1 & Benar \\
\hline 25 & 3 & 3 & Benar \\
\hline 26 & 3 & 3 & Benar \\
\hline 27 & 3 & 3 & Benar \\
\hline 28 & 3 & 3 & Benar \\
\hline 29 & 3 & 3 & Benar \\
\hline 30 & 3 & 3 & Benar \\
\hline 31 & 2 & 2 & Benar \\
\hline 32 & 2 & 2 & Benar \\
\hline 33 & 2 & 2 & Benar \\
\hline \multicolumn{3}{|c|}{ Persentase unjuk kerja } & $100 \%$ \\
\hline
\end{tabular}

Berdasarkan Tabel 3. alfa 0.5 dan dec alfa 0.75 memiliki persentase tertinggi dengan persentase $100 \%$. Dengan menggunakan parameter tersebut diambil bobot akhir untuk proses pengujian. Dari pengujian yang dilakukan terhadap data uji sebanyak 33 dengan menggunakan parameter tersebut dapat menghasilkan persentase keberhasilan mencapai $100 \%$. Dengan demikian parameter LVQ yang digunakan untuk melakukan deteksi buta warna adalah dengan alfa 0.5 dan dec alfa 0.75 . 


\section{KESIMPULAN}

Berdasarkan pengujian yang dilakukan, kesimpulan yang diperoleh adalah sebagai berikut:

1. Learning Vector Quantization dapat digunakan sebagai mesin inferensi dalam sistem pakar deteksi buta warna.

2. Parameter LVQ yang digunakan adalah alfa 0.5 dan dec alfa 0.75 , dengan data pelatihan sebesar 35 dengan data uji 33 .

3. Unjuk kerja pengujian LVQ buta warna sesuai dengan basis pengetahuan dengan tingkat persentase keberhasilan yaitu $100 \%$.

4. Unjuk kerja pengujian sistem pakar buta warna sesuai dengan basis pengetahuan dengan tingkat persentase keberhasilan yaitu $100 \%$.

\section{DAFTAR PUSTAKA}

Ananto, Bayu. S. 2011. Implementasi Sistem Bantuan Penderita Buta Warna: Desain Antarmuka Pengguna, Sistem Buta Warna dengan Ishihara, Dan Transformasi Warna Pada Sistem Realitas Tertambah. Skripsi Universitas Indonesia.

Arhami, Muhammad. 2005. Konsep Dasar Sistem Pakar. Yogyakarta: Andi

Murti, Hari. S.Kom, M.Cs, Santi Rina. C. N, S.Pd, M.Kom, 2011. Model Pendiagnosa Kebutaan Warna Dengan Menggunakan Metode Ishihara. Diakses pada 6 Maret 2016. Dari ejournal Universitas Stikubank.

Prabawati, Puspita. 2015. Sistem Pakar Diagnosa Buta Warna Berbasis Android. Skripsi Universitas Negeri Semarang.

Purnamasari, Prasetya. 2015. Tes Buta Warna Metode Ishihara Berbasis Komputer (Kelas XI Jurusan Teknik Instalasi Tenaga Listik SMK Negeri 3 Semarang). Skripsi Universitas Negeri Semarang.

Rokhim, Ahmad. N. 2015. Mengenal Tes Buta Warna. Yogyakarta:Rona Publishing.

Widianingsih, R., Krisdalaksana, A. H., Hakim, A. R., 2010. Aplikasi Tes Buta Warna Dengan Metode Ishihara Berbasis Komputer. Diakses pada 6 Maret 2016. Dari ejournal Universitas Mulawarman.

Widodo, Thomas S., 2005, Sistem Neuro Fuzzy untuk pengolahan Informasi, Pemodelan, dan Kendali., Yogyakarta: Graha Ilmu. 
36 Jurnal Multimedia \& Artificial Intelligence, Volume 1, Nomor 2, Agustus 2017 